\title{
Successful treatment of acute hemoptysis of bronchiectasis by thoracoscopic bronchial artery ligation
}

\author{
W Hsing-Hsien \\ From 23rd World Congress of the World Society of Cardio-Thoracic Surgeons \\ Split, Croatia. 12-15 September 2013
}

\section{Background}

Acute massive hemoptysis is a life-threatening condition. Traditionally, bronchial artery embolization and lung resection are the treatment options. But there is high recurrence rate after bronchial artery embolization and some patients are not suitable for or can't tolerate lung resection. We develop thoracoscopic bronchial artery ligation as another treatment option. This is the first report to apply this procedure in treatment of acute life-threatening hemoptysis in bronchiectasis.

\section{Methods}

A 46-year-old male patient visited the emergency department due to cough up of bloody contents on December 14th in 2010. The hemoptysis ever developed 3 months ago and relieved after medical treatment. The reformatted imaging revealed engorged bronchial artery from descending aorta. Emergent thoracoscopic surgery was arranged. Bronchoscopy was done firstly after general anesthesia. Then bronchial artery ligation with clipping and wedge resection were performed. Bronchoscopy was performed again to clean out the blood clots.

\section{Results}

The operative course was smooth. The postoperative recovery was uneventful. The chest was removed on the next day after surgery. The patient was discharged on the postoperative third day. The patient was followed till now. The hemoptysis no more attacked again.

Correspondence: kenwu489@gmail.com

Department of Thoracic Surgery, Tainan Municipal Hospital, Tainan City, Taiwan

\section{Conclusions}

Life-threatening hemoptysis is an emergent condition. Traditionally bronchial artery embolization individual, pulmonary resection or both are the treatment options. The procedure is safe and effective. This procedure individual or combined with pulmonary resection may become a new option in treatment of acute hemoptysis.

Published: 11 September 2013

doi:10.1186/1749-8090-8-S1-P27

Cite this article as: Hsing-Hsien: Successful treatment of acute

hemoptysis of bronchiectasis by thoracoscopic bronchial artery ligation. Journal of Cardiothoracic Surgery 2013 8(Suppl 1):P27.

Submit your next manuscript to BioMed Central and take full advantage of:

- Convenient online submission

- Thorough peer review

- No space constraints or color figure charges

- Immediate publication on acceptance

- Inclusion in PubMed, CAS, Scopus and Google Scholar

- Research which is freely available for redistribution \\ () Biomed Central}

